\title{
Pineapple (Ananas comosus L. Merr.), Waste Streams, Characterisation and Valorisation: An Overview
}

\author{
Wafaa M. Hikal1,2*, Abeer A. Mahmoud ${ }^{3}$, Hussein A. H. Said-Al Ahl ${ }^{*}$, Amra Bratovcic ${ }^{5}$, \\ Kirill G. Tkachenko6, Miroslava Kačániová7,8, Ronald Maldonado Rodriguez ${ }^{9}$
}

\author{
${ }^{1}$ Department of Biology, Faculty of Science, University of Tabuk, Tabuk, Saudi Arabia \\ ${ }^{2}$ Water Pollution Research Department, Environmental Research Division, National Research Centre, 33 El-Bohouth St., Dokki, \\ Giza, Egypt \\ ${ }^{3}$ Department of Botany (Plant Physiology Section), Faculty of Agriculture, Cairo University, Giza, Egypt \\ ${ }^{4}$ Medicinal and Aromatic Plants Research Department, National Research Centre, 33 El-Bohouth St., Dokki, Giza, Egypt \\ ${ }^{5}$ Department of Physical Chemistry and Electrochemistry, Faculty of Technology, University of Tuzla, Tuzla, Bosnia and \\ Herzegovina \\ ${ }^{6}$ V. L. Komarov Botanical Institute of the Russian Academy of Sciences, Saint Petersburg, Russia \\ ${ }^{7}$ Department of Fruit Science, Viticulture and Enology, Faculty of Horticulture and Landscape Engineering, Slovak University of \\ Agriculture, Nitra, Slovakia \\ ${ }^{8}$ Department of Bioenergetics, Food Analysis and Microbiology, Institute of Food Technology and Nutrition, University of \\ Rzeszow, Cwiklinskiej 1, Rzeszow, Poland \\ ${ }^{9}$ The Fluoromatics Laboratory, 10 Rue du Vieux-Moulin, 1213 Onex, Geneva, Switzerland \\ Email: *wafaahikal@gmail.com, *shussein272@yahoo.com
}

How to cite this paper: Hikal, W.M., Mahmoud, A.A., Said-Al Ahl, H.A.H., Bratovcic, A., Tkachenko, K.G., Kačániová, M. and Rodriguez, R.M. (2021) Pineapple (Ananas comosus L. Merr.), Waste Streams, Characterisation and Valorisation: An Overview. Open Journal of Ecology, 11, 610-634. https://doi.org/10.4236/oje.2021.119039

Received: July 27, 2021

Accepted: August 31, 2021

Published: September 3, 2021

Copyright (c) 2021 by author(s) and Scientific Research Publishing Inc. This work is licensed under the Creative Commons Attribution International License (CC BY 4.0).

http://creativecommons.org/licenses/by/4.0/

\begin{abstract}
Processing pineapple industry produces huge amounts of waste thus contributing to worsen the global environmental problem. Valorising pineapple waste through further processing until it is transformed into valuable products using environmentally friendly techniques is both, a challenge, and an opportunity. The aim of this review is to characterize and highlight the phytochemical constituents of pineapple peel, their biological activity, and to evaluate the current state-of-art for the utilization of pineapple waste from the processing industry for obtaining pharmaceuticals, food, and beverages, biocombustibles, biodegradable fibers, and other different usage. Pineapple residues are rich in many bioactive compounds such as ferulic acid, vitamin $\mathrm{A}$ and $\mathrm{C}$ as antioxidant, and containing alkaloids, flavonoids, saponins, tannins, cardiac glycoside, steroids, triterpenoids and phytosterols may provide a good source of several beneficial properties, as well as bromelain that showed significant anticancer activity. Also, pineapple processing residues contain important volatile compounds used as aroma enhancing products and have high potential to produce value-added natural essences. Pineapple peels can be used as non-
\end{abstract}


pharmacological therapeutical in the form of processed food and instant drinks; its potent natural antimicrobial properties may be applied for food conservation and as potential leads to discover new drugs to control some infectious microbial. Pineapple waste is a promising source of metabolites for therapeutics, functional foods, and cosmeceutical applications.

\section{Keywords}

Pineapple Peel, Ananas comosus, Phytochemical Constituents, Antioxidant Activity, Anticancer, Antimicrobial Activities

\section{Introduction}

Pineapple (Ananas comosus L. Merr.) is a tropical fruit belonging to the family of Bromeliaceae [1], having a short stem and slender hard leaves that grow to medium to large-sized fruit. It is the third most important tropical fruit produced globally after bananas and mangos. It is native to South America in Brazil and Paraguay, and often referred to as pineapple. The fruit was spread from native to South and Central America, when the Guarani Indians took A. comosus on sea voyages as provisions and to prevent scurvy. When Columbus found the fruit in 1493 called it pina, because he thought it looked like a pin cone. The hybrids known today first appear, when the Dutch improved the fruit by crossbreeding, around 1700. The cuttings of the plants were sold to English, who grew them as pot-house plants [2] [3].

Pineapple is a medium tall $(1-1.5 \mathrm{~m})$ herbaceous perennial plant with 30 or more trough-shaped and pointed leaves $30-100 \mathrm{~cm}$ long, surrounding a thick stem. A. comosus is an example of a multiple fruit: multiple, spirally arranged flowers along the axis each produce a fresh fruit that becomes pressed against the fruits of adjacent flowers, forming what appears to be a single fleshy fruit. The fruit lets of $A$. comosus are arranged in two interlocking spirals, eight spirals direction, thirteen in the other; each being a Fibonacci number. Pollination is required for seed formation; the presence of seeds negatively affects the quality of the fruit [2] [3]. Pineapple is not a single fruit but a composite of many, originated from flowers whose individual fruit fuse together around a central core. Each fruit let can be identified by the rough spiny marking on the A. comosus surface. Pineapple has a wide cylindrical shape, a scaly green, brown, or yellow skin and a regal crown of spiny, blue-green leaves. The fibrous flesh of $A$. comosus is yellow in colour and has a vibrant tropical flavour that balances the testes of sweet and tart. The area closer to the base of the fruit has more sugar content and therefore a sweeter taste and more tender texture [2] [3]. Table 1 and Figure 1 show the pineapple production worldwide in 2019.

The pineapple has a world production of 25.4 million metric tonnes. The consumption of the pineapple is wide due to its sweet and acidic flavour and varies as it is consumed fresh, cooked, juiced, or preserved. The tropical fruit is an ex- 
cellent source of vitamins, minerals, and nutrients and is rich in antioxidants. Pineapples are made up of a cluster of multiple berries that grow within the second year of cultivation and are harvested one year later. Pineapples best grow in subtropical and tropical areas where the weather is warm, but cool at night [1] [4].

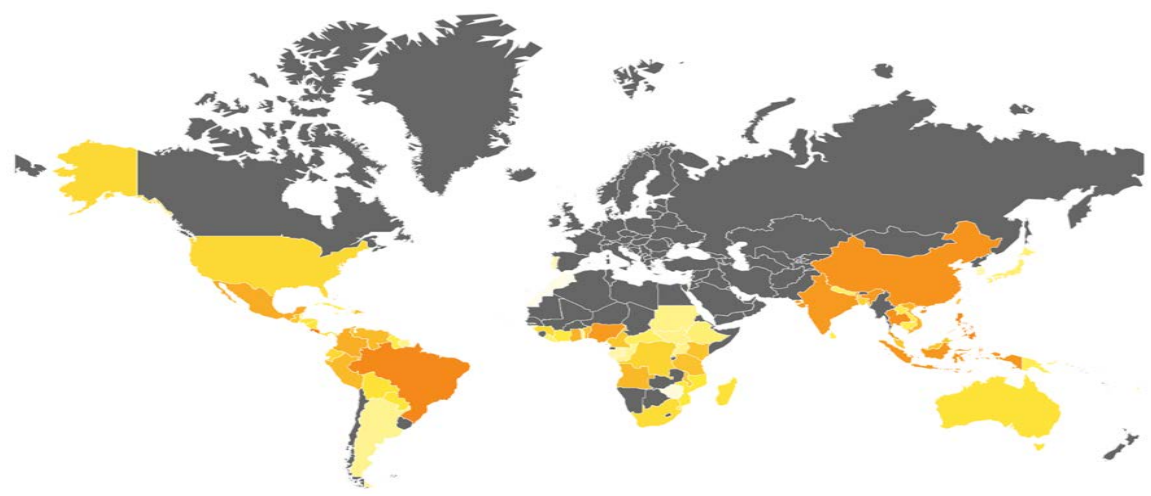

Figure 1. Pineapple producing countries.

Table 1. Countries in pineapple production worldwide in 2019 [FAO, 2021].

\begin{tabular}{|c|c|}
\hline Country & Value (Tonnes) \\
\hline Angola & 870,257 \\
\hline Antigua and Barbuda & 494 \\
\hline Argentina & 3278 \\
\hline Australia & 86,201 \\
\hline Bangladesh & 217,439 \\
\hline Belize & 3585 \\
\hline Benin & 355,854 \\
\hline Bolivia & 87,658 \\
\hline Brazil & $2,426,526$ \\
\hline Brunei Darussalam & 1207 \\
\hline Cambodia & 25,797 \\
\hline Cameroon & 348,340 \\
\hline Central African Republic & 17,225 \\
\hline China & $2,158,691$ \\
\hline China, mainland & $1,727,607$ \\
\hline China, Taiwan Province & 431,084 \\
\hline Colombia & $1,008,687$ \\
\hline Congo & 3412 \\
\hline Cook Islands & 25 \\
\hline Costa Rica & $3,328,100$ \\
\hline Côte d'Ivoire & 41,151 \\
\hline
\end{tabular}




\section{Continued}

\begin{tabular}{|c|c|}
\hline Cuba & 40,301 \\
\hline Democratic Republic of the Congo & 193,367 \\
\hline Dominica & 133 \\
\hline Dominican Republic & 461,025 \\
\hline Ecuador & 46,348 \\
\hline El Salvador & 1136 \\
\hline Eswatini & 2043 \\
\hline Ethiopia & 1164 \\
\hline Fiji & 7158 \\
\hline French Polynesia & 4079 \\
\hline Gabon & 1473 \\
\hline Ghana & 743,098 \\
\hline Grenada & 382 \\
\hline Guatemala & 358,560 \\
\hline Guinea & 139,027 \\
\hline Guinea-Bissau & 469 \\
\hline Guyana & 29,944 \\
\hline Haiti & 8289 \\
\hline Honduras & 69,943 \\
\hline India & $1,711,000$ \\
\hline Indonesia & $2,196,456$ \\
\hline Israel & 282 \\
\hline Jamaica & 33,938 \\
\hline Japan & 6297 \\
\hline Kenya & 278,179 \\
\hline Lao People’s Democratic Republic & 43,466 \\
\hline Liberia & 9241 \\
\hline Madagascar & 104,603 \\
\hline Malawi & 300,000 \\
\hline Malaysia & 299,912 \\
\hline Mauritius & 8459 \\
\hline Mexico & $1,041,161$ \\
\hline Mozambique & 65,569 \\
\hline Nepal & 13,846 \\
\hline Nicaragua & 70,253 \\
\hline Nigeria & $1,671,440$ \\
\hline Panama & 111,070 \\
\hline Papua New Guinea & 23,368 \\
\hline
\end{tabular}




\section{Continued}

\begin{tabular}{|c|c|}
\hline Paraguay & 85,216 \\
\hline Peru & 568,907 \\
\hline Philippines & $2,747,856$ \\
\hline Puerto Rico & 3871 \\
\hline Republic of Korea & 976 \\
\hline Rwanda & 36,372 \\
\hline Saint Lucia & 55 \\
\hline Samoa & 4435 \\
\hline Seychelles & 20 \\
\hline South Africa & 115,106 \\
\hline South Sudan & 6500 \\
\hline Sri Lanka & 43,001 \\
\hline Sudan & 1500 \\
\hline Suriname & 3899 \\
\hline Thailand & $1,679,668$ \\
\hline Timor-Leste & 103 \\
\hline Togo & 2061 \\
\hline Trinidad and Tobago & 2795 \\
\hline Uganda & 4072 \\
\hline United Republic of Tanzania & 454,008 \\
\hline United States of America & 144,569 \\
\hline Venezuela & 485,964 \\
\hline Viet Nam & 707,880 \\
\hline Zimbabwe & 144 \\
\hline
\end{tabular}

The pineapple has a world production of 25.4 million metric tonnes. The consumption of the pineapple is wide due to its sweet and acidic flavour and varies as it is consumed fresh, cooked, juiced, or preserved. The tropical fruit is an excellent source of vitamins, minerals, and nutrients and is rich in antioxidants. Pineapples are made up of a cluster of multiple berries that grow within the second year of cultivation and are harvested one year later. Pineapples best grow in subtropical and tropical areas where the weather is warm, but cool at night [1] [4].

There are four varieties of Pineapple available worldwide: Smooth Cayenne, Red Spanish, Queen, and Abacaxi [5] [6]. Pineapples are cultivated on more than a million hectares of soil, resulting in US\$ 9 billion to the global economy annually [7] [8]. The main pineapple varieties for commercial use are Smooth Cayenne, Singapore Spanish, Red Spanish and Selangor Green [9]. In Brazil, the most popular varieties are Perola and Smooth Cayenne [10]. Cost Arica, India, Thailand, Philippines, Brazil, China, Nigeria, Mexico, Indonesia, Columbia are the leading producers (Figure 2). 


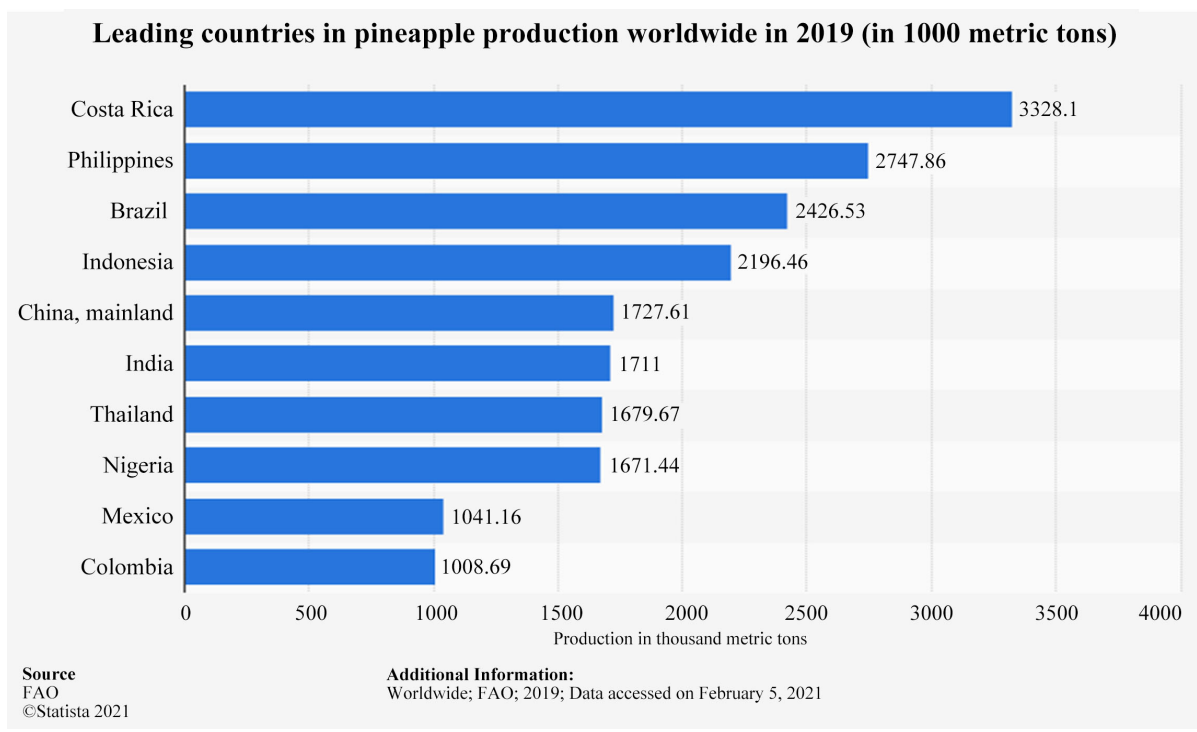

Figure 2. Top 10 countries in pineapple production (2019) [FAO, 2021].

Approximately, $60 \%$ of the pineapple fruits are edible, thus processing residuals range between $45 \%$ to $65 \%$ [11]. The crown and stem of the pineapple are cut off before peeling and the centre is eliminated during processing. All these wastes like core, peel, stem, crown, and leaves account for about $50 \%(\mathrm{w} / \mathrm{w})$ of general pineapple weight. Two types of waste may be labelled from pineapple production: POFW (pineapple on farm waste) and PPW (pineapple peel waste). POFW normally involves leaves, roots, and stem leftovers at the farm. Pineapple is processed in many methods inside the pineapple product zone, together with slicing, pulping, and juicing. Before the pineapple product changed into processed, exclusive steps were taken to get rid of the crown, then put off the peels and core. A one-of-a-kind volume of PPW is generated through every step. Researchers located that $9.12 \%$ of middle, $13.48 \%$ of peels, $14.4 \%$ of pulp, $14.87 \%$ of the top, and $48.04 \%$ of completed products have been produced by using pineapple. Therefore, with increasing pineapple production, pineapple waste increases proportionally. Waste disposal is a growing issue because it is usually prone to microbial spoilage and causes serious environmental problems. It directly represents the enormous challenge of pineapple waste disposal, which will further lead to environmental pollution if not successfully used [11].

Due to their pleasant aroma and its attractive sweet flavour, pineapple is widely consumed fresh, canned, in processed juices, and as an ingredient in exotic foods [12], and its derived products are popular. Besides its sweet flavour, pineapple is very wealthy in essential nutrients consisting of potassium, calcium, phosphorus and iron, vitamin C, copper, folate, glycans, fibers, and different crucial factors. All these substances make pineapple an excellent candidate for part of a balanced dietary weight-reduction plan. One of the most favourable aspects of its composition is that it consists of a minimum amount of fat and sodium, but incorporates high quantities of carbohydrates [13] [14]. 
Pineapple canning industries produce large quantity of solid waste. The dry matter content of pineapple waste is around $10 \%$, composed of about $96 \%$ organic matter and 4\% inorganic matter [15]. According to Conesa et al. [16], in the elaboration of pineapple-based food products, this value can be $50 \%$. Other authors reported a waste production from pineapples processing in the range of $25 \%-35 \%$ of the weight of the fruit [17]. This discrepancy can be due to pineapple variety and the type of processing used. Worldwide, agricultural industries generate large amounts of bio-mass residues which can cause environmental and pollution concerns [18]. Wastes derived from food processing are identified as major resources for the bio-based processes development [19] [20] and a sustainable use of these food by-products to produce value-added products (as chemicals, materials, and fuels) could contribute to reduce environmental concerns and improvement of economic growth. Taking this in consideration, strategies are needed to recover other added value compounds available in pineapple wastes. Figure 3 shows pineapple wastes.

\section{Bioactive Components in Pineapple Waste}

Pineapple waste is a rich source of bioactive components. Pineapple primarily has its waste in the form of crown, peel, stem, and core. There is a different bioactive compound present in each portion. For example, citric acid in pineapple leaves, bromelain in the leaves, stem, and peel, ferulic acid in the leaves, ascorbic acid in the core [4]. Moreover, phenolic compounds also found in pineapple residues are of great interest in the pharmaceutical and food industry due to their biological properties with application on human health, examples as myricetin, salicylic acid, tannic acid, trans-cinnamic acid and p-coumaric acid identified in a high dietary fiber powder from pineapple shell which is a part of waste and these compounds were reported as potent antioxidants [21]. On the other hand, it has been shown that the polyphenols found from pineapple wastes such as

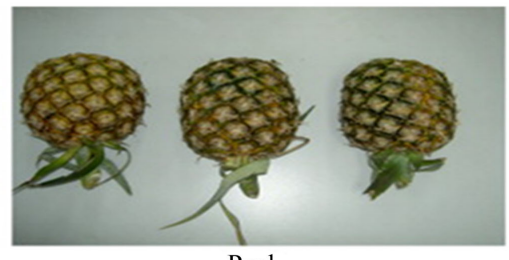

Peel

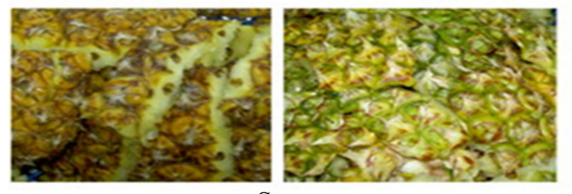

Stem

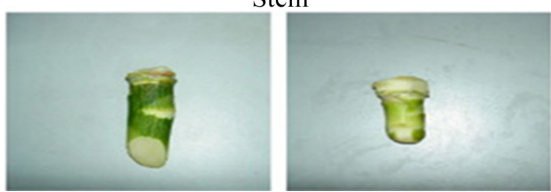

Figure 3. Pineapple wastes.

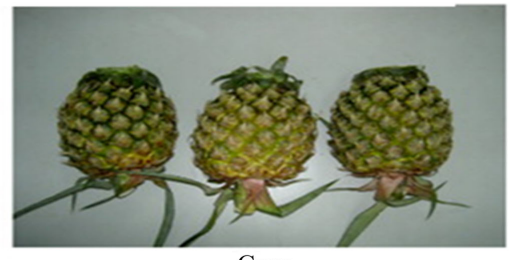

Core

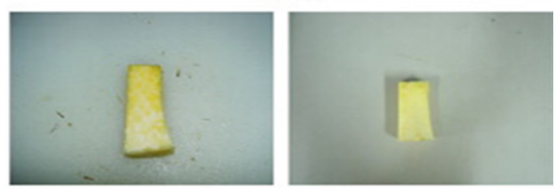

Crown

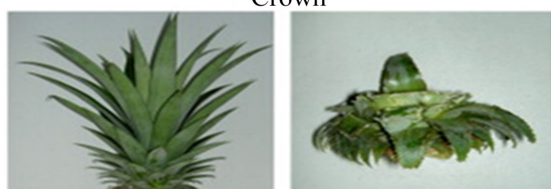


ferulic acid and syringic acid, are responsible for antioxidant and antimicrobial activity [22]. Also, glycosides obtained from these residues have various applications as food additives, prebiotics, and bio preservatives [23]. Also, pineapple waste is an enriched raw material, as insoluble fibers, pectins, sugars, protein, vitamins, minerals and phenolic compounds [24] [25] [26] [27], and bromelain, a group of proteases with different applications in the food, textile, cosmetics and others [28].

Pineapple fruit is rich in vitamins A and C, flavonoids, tannins, and other polyphenolic compounds, organic acids, and soluble monosaccharides and disaccharides (up to 15\%). Carotenoids are the source of characteristic fruit colour, while the flavour comes from a very complex mix of substances where oxygenated aliphatic compounds have the main role. Stem and full-grown fruit contain proteolytic enzyme that breaks down protein, bromelain, which belongs to the group of endopeptidases [11] [29]. Pineapple fruit is also low in sodium and rich in potassium [2] [3]. Pineapple residue contains high concentrations of vitamins, sugars, fibers, and other constituents which can be used for human consumption [30]. Previous scientific studies have reported the use of pineapple processing residue for citric acid extraction [31], phenolic compounds production [31], bromelain from stem and rind [31], hydrogel from peel cellulose [31], nanocellulose from leaf fibres [32].

The canning industry is producing large quantities of solid and liquid wastes, could be a potential source for the extraction of beneficial bioactive compounds including bromelain [33] [34], fibers, protein, carotenoid, mineral composition, total polyphenol content [35] [36]. Gallic acid (31.76 mg/100g dry extracts), catechin $(58.51 \mathrm{mg} / 100 \mathrm{~g})$, epicatechin $(50.00 \mathrm{mg} / 100 \mathrm{~g})$, and ferulic acid $(19.50$ $\mathrm{mg} / 100 \mathrm{~g}$ ) were found to be the main polyphenolics in pineapple peels [37], vitamin C, carotenoid, phenolic compounds, flavonoids [38] [39] [40] [41]. Arsyada et al. [42], reported that pineapple peel extract contains chemical compounds namely: flavonoids, saponins, tannins, and enzymes bromelain and flavonoids were the highest concentration of chemical compounds in pineapple peel extract. Also, pineapple is a rich source of manganese, which helps build and maintain bone strength and it also has plenty of vitamin C. It also contains bromelain, that can reduce swelling, bruising, healing time and pain associated with injury and surgical intervention [43]. The phytochemical analysis of the pineapple peel showed that, alkaloids, flavonoids and saponin had the highest abundance of the phytochemical properties; and phenolic, tannins and terpenoids were present as moderately as well as glycoside and steroids as trace amount [44]. Chlorogenic acid and ferulic acid in aqueous pineapple extract is considered having an important role as reducing agent or antioxidant [45].

The aroma volatile compounds are important properties of fruits and are vital factors to determine the attributes of fresh and processed fruit [31]. Many volatiles have been identified in the pineapple fruit and its derivatives [31] [46] [47] [48] [49]. Barretto et al. [50], identified volatile compounds from pineapple residues, using two techniques: simple hydrodistillation and hydrodistillation by passing ni- 
trogen gas. Among the identified components were esters (37\%), alcohols (29\%), aldehydes (9\%), ketones (9\%), acids (6\%), and other compounds (11\%). The main volatile compounds identified in the distillate of pineapple processing residue obtained by simple hydrodistillation were (Z)-3-hexen-1-ol (35.58\%), methyl octanoate (26.11\%), 2-phenyl-1-ethanol (13.51\%), 2-methyl-3-buten-2-ol (8.69\%), and 1-hexanol (3.84\%). By hydrodistillation by passing nitrogen gas, Pineapple processing residue was composed mainly of esters (35\%), followed by ketones (26\%), alcohols (18\%), aldehydes (9\%), acids (3\%), and other compounds (9\%). The major volatile compounds obtained by hydrodistillation by passing nitrogen gas were 1-hexanol (60.19\%), ethyl phenyl-acetate (14.54\%), 2-methyl-3-buten-2-ol (9.33\%), $\gamma$-butyrolactone (2.08\%), 2-phenyl ethyl-acetate (1.72\%), and ethyl octanoate (1.19\%). This suggests that the use of an inert gas and lower temperatures helped maintain higher amounts of flavor compounds. These data indicate that pineapple processing residue contained important volatile compounds which can be extracted and used as aroma enhancing products and have high potential to produce value-added natural essences [50].

Wei et al. [51] identified 44 volatile compounds from pineapple pulp and core. Some of them were methyl hexanoate, ethyl hexanoate, methyl 3-(methylthio) propanoate, methyl octanoate, ethyl decanoate, $\alpha$-terpineol, nonanal, and decanal. However, the ones with the highest odor activity values were ethyl hexanoate, nonanal, and decanal. Morais and Silva [46] emphasized that ethyl hexanoate is one of the most important compounds related to the pineapple flavor. Also, they found ethyl hexanoate is an important pineapple aroma volatile compound with decanal, ethyl octanoate, acetic acid, 1-hexanol, and many ketones such as $\gamma$ hexalactone, $\gamma$-octalactone, $\delta$-octalactone, $\gamma$-decalactone and $\gamma$-dodecalactone. According to Facundo [47], the compound ethyl hexanoate is related to the aroma note described as "pineapple". This compound was also identified in the pineapple processing residue distillate obtained by simple hydrodistillation technique, beside Ethyl octanoate, 2-heptanone, and $\gamma$-hexalactone [47]. Tokitomo et al. [52] detected 29 odor-active compounds, some of them were $\gamma$-octalactone, $\delta$-octalactone, $\gamma$-decalactone, and $\gamma$-dodecalactone. Also, Elss et al. [48] reported the presence of the following volatile compounds of fresh pineapple juice and its water phase extracts: 2-methyl-3-buten-2-ol, methyl pentanoate, butyl acetate, hexanal, 2-pentanol, 1-butanol, ethyl hexanoate, limonene, z-ocimene, linalool, furfural, acetic acid, $\alpha$-terpineol, geraniol, and $\gamma$-octalactone. As well as, Spanier et al. [49] analyzed volatile components present in fresh-cut pineapple and the effect of its storage such as acetic acid, 1-hexanol, and nonanal. Zhang et al. [53], reported that 57 volatile compounds were detected of pineapple peel oil including 25 esters, 9 alcohols, 8 acids, 7 phenolic compounds, 6 aldehydes and ketones, 1 terpene and 1 lactone. The content of alcohols is the largest. Phenethyl alcohol (22.18\%), 3methyl-1-butano (6.91\%), 2-methyl-1-butano (4.75\%), 2,3-butanediol (8.35\%), 2methoxy-4-vinylphenol (5.66\%) and octanoic acid (4.29\%) were the major constituents. 
The number of publications for the term, Pineapple peel waste on ScienceDirect clearly shows that scientists started intensive research only 6 years ago, but it has been particularly pronounced in the last two years. Figure 4 shows the graphical number of reported publications in the last sixteen years.

\section{The Advantages (Benefits) of Pineapple Waste}

\subsection{Antioxidant Capacity of Pineapple Peels}

de Oliveira et al. [54] have concentrated on the antioxidant capacity of pineapples. They studied the total phenolic content and antioxidant activities of methanolic extracts of pineapple residues (including pulp, seeds, and peels from a local juice factory) using DPPH and superoxide anion scavenging activity. Hossain et al. [37] extracted total polyphenols of pineapple with different solvents, and the results showed that the polyphenolic contents of the extracts were found to be highest in methanol corresponding to the highest antioxidant properties. Gallic acid, catechin, epicatechin, and ferulic acid were found to be the main polyphenolics in pineapple peels. Results of polyphenolics' interactions indicated no synergistic effects. In the combinations of ferulic acid-epicatechin and ferulic acidgallic acid, additive effects were found using both antioxidant activity assays [55]. However, some researchers have reported that pineapple peel is a potential source of bioactive compounds, such as vitamin $\mathrm{C}$, carotenoid, phenolic compounds, flavonoids [38] [39] [40] [41], and these compounds have been reported to have antioxidant activity and various biological activities [21] [56] [57]. However, these bioactive compounds are varied depending on many factors, including cultivar, pre-and postharvest treatment and particularly method for raw material and extract preparation [58] [59] [60] [61] [62]. Also, some studies confirmed the antioxidant activity of pineapple peel extract [31] [63] [64] [65]. Chlorogenic acid and ferulic acid in aqueous pineapple extract is considered having an important role as reducing agent or antioxidant [44].

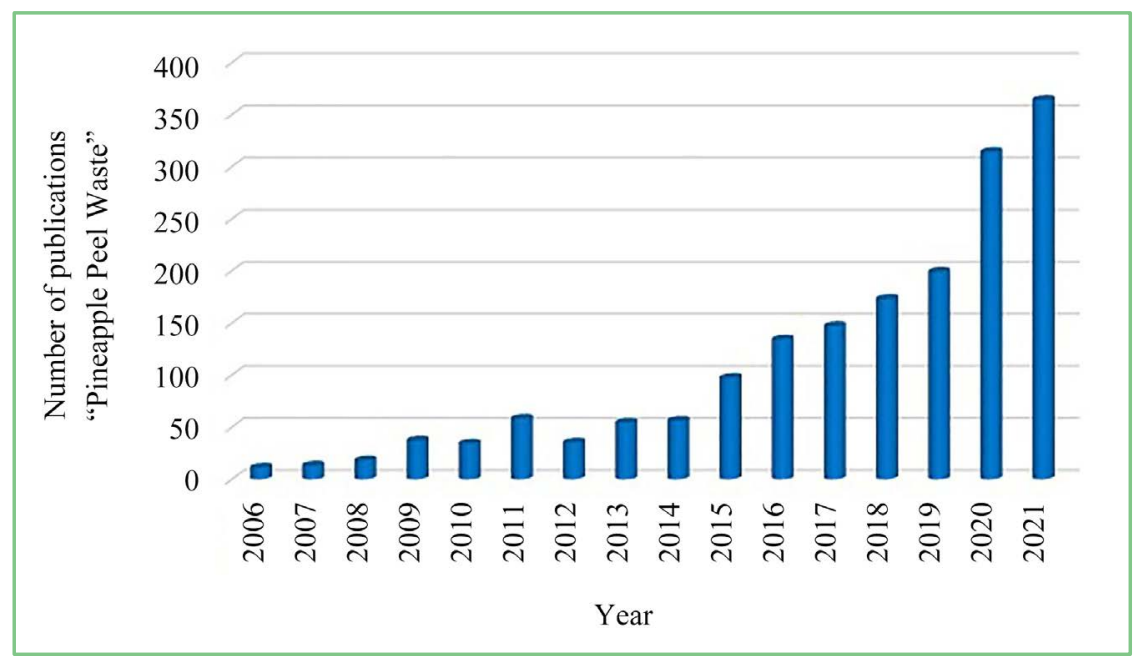

Figure 4. The graphical number of publications on ScienceDirect in the last sixteen years for pineapple peel waste. 


\subsection{Anticancer Activity}

Ferulic acid is a hydroxycinnamic acid, a type of organic compound. It is an abundant phenolic photochemical found in extracted from pineapple peel. It is related to trans-cinnamic acid and contributes to the antibacterial, anticancer activity and antioxidant properties of the plant [66]. The antioxidant potential for extracted and standard ferulic acid was calculated by DPPH assay of $87.3 \%$ and $81.92 \%$ respectively and the total antioxidant capacity was calculated by FRAP assay which is expressed as $2315 \mu \mathrm{M}$ and $3985 \mu \mathrm{M}$. The anticancer activity of extracted ferulic acid was evaluated based on viability of cells using MTT assay. The optimum cell viability was $48.04 \%$ at a concentration $125 \mu \mathrm{g} / \mathrm{ml}$ and the maximum cell viability was $91.63 \%$ obtained at the concentration of $7.8 \mu \mathrm{g} / \mathrm{ml}$ using MTT assay. So, pineapple is a potent source of ferulic acid that can be extracted and used as anticancer and antioxidant [66]. Bromelain also showed significant anticancer activity against breast cancer cells, melanoma cells, human epidermoid carcinoma cells, malignant peritoneal mesothelioma cells and mammary carcinoma cells. The major anticancer mechanism of bromelain is by inhibiting cancer cell proliferation and inducing differentiation of leukemic cells [31].

\subsection{Antibacterial Activity}

Recycling pineapple wastes by using pineapple waste as potential lead to discover new drugs to control some food poisoning and other infectious bacteria is a promising aim. Lubaina et al. [67] showed that the antibacterial potential exhibited by ethyl acetate extract of pineapple peel was effective against gram-positive and gram-negative bacterial strains such as Staphylococcus aureus (ATCC 29213), Escherichia coli (ATCC 25922), Pseudomonas aeruginosa (ATCC 27853), Vibrio cholera (MCV09) and Klebsiella pneumoniae (ATCC 700603). From the results it can be concluded that pineapple peel could be a useful source for antibiotic production and has the potential of medicinal and industrial application. Antimicrobial properties of various extracts from pineapple peel have recently been of great interest because of their possible use as natural additives emerged from a growing tendency to replace synthetic antimicrobials with natural ones [67]. Das et al. [68] reported antioxidant, antibacterial, antidiabetic, and cytotoxicity of pineapple peel.

The antibacterial activity revealed by the pineapple extracts might be due to presence of polyphenols, flavonoids, saponins and other secondary metabolites present in the extract. Flavonoids and polyphenols are more potent in inhibiting gram-positive bacteria. Both are phenolic compounds which have polar properties mostly work in the peptidoglycan layer in gram-positive bacteria rather than the non-polar lipid layer. Most plant phenolic compounds are non-toxic for human consumption therefore they could be used to prevent growth of many foodborne and food spoilage microorganisms. These phenols have the ability to denatures the protein and its lipophilic nature helps them to attract the lipid mole- 
cules contained in the cell membranes and damage the bacterial cell membrane [69]. Both bromelain and saponins act on bacterial cell wall and membranes. The active compound working against gram-negative bacteria is mainly bromelain. Bromelain is a proteolytic enzyme play a role in the breakdown of proteins, one of the essential components in bacterial membrane causing injury and cell death. It also disintegrates protein in surface membrane which eventually weakens the cell wall, leads to cell leakage and damages the cell. The numbers of amino acids in the bacterial cell wall are thought to determine the antibacterial activity of proteolytic enzymes. Saponins increases the permeability of the bacterial cell membrane, causing alteration in the structure and function of the membrane thereby disrupting the surface tension of the cell wall and allowing antibacterial substances to easily enter the cells and interfere the cell metabolism which in turn leads to the lysis of membrane. Saponins selectively interact with cholesterols on cell membrane leaving a hole in the membrane [70]. Phenols alter the permeability of the membrane that could result in the uncoupling of oxidative phosphorylation, inhibition of active transport, and loss of metabolites due to membrane damage. Polyphenols inhibit bacterial DNA gyrase by binding to the ATP binding site [71]. Gallic acid has proven antifungal and antibacterial properties [72]. Similarly, tannins exert antimicrobial activities by iron deprivation, hydrogen binding or specific interactions with vital proteins, such as enzymes in microbial cells, bind to adhesions, complex with cell wall, other membranes and metal ion complexes. Flavonoids are also possessing antimicrobial potential by link to adhesions or complexes with the cell wall, inactivation of enzymes and inhibition of HIV reverse transcriptase [73].

Bromelain is an extract isolated from pineapple mainly containing proteinase. It is a crude, aqueous extract showed significant antibacterial activity against gram negative and gram-positive bacteria such as Bacillus subtilis, Streptococcus pyogenes, Corynebacterium spp, Streptococcus sanguis (10556 ATCC), Enterococcus faecalis, Escherichia coli, Proteus spp and Pseudomonas aeruginosa. The anti-bacterial mechanism of bromelain is not well known but, it may inhibit the growth of bacteria through hydrolysis of some peptide bonds present in the bacterial cell wall [31]. Bromelain was extracted from all parts of pineapple. Bromelain was tested for antibacterial activity against bacterial pathogens. Among them, Pulp bromelain had maximum inhibition effect on Bacillus subtilis, Klebsiella pneumonia and Core bromelain had maximum inhibitory effect on Bacillus subtilis, Proteus vulgaris, Schigella flexneri and Escherichia coli and there was no inhibitory activity for the other tested pathogens [74]. Das et al. [68] investigated the antimicrobial activity of pineapple peel (PP) extract (PPE) to observe possibility of using it as a natural antimicrobial agent in food. The antimicrobial activity of the PPE was performed against some food pathogens (Bacillus cereus, Staphylococcus aureus, Salmonella typhimurium and Escherichia coli). In addition, the gram-positive bacteria tended to be more susceptible to the PPE than the gram negative one. $B$. cereus exhibited the most sensitive strain with mini- 
mum inhibition concentration (MIC) of $0.0675 \mathrm{~g} / \mathrm{mL}$, followed by $S$. aureus and E. coli $(0.1349 \mathrm{~g} / \mathrm{mL})$ and $S$. typhimurium $(0.2699 \mathrm{~g} / \mathrm{mL})$, respectively. In addition, the minimum bactericidal concentration (MBC) against all the tested bacteria in broth dilution assay was $0.0675 \mathrm{~g} / \mathrm{mL}$, except $B$. cereus, in which the lethally effect was not detected. The results suggested that the pineapple peel extract is a potent natural antimicrobial agent for food application. IUPAC name for Bromelain is N-[(2S,3R,4R,5S,6R) 2-[(2R,3S,4R,5R)-5-acetamido-6-hydroxy2-(hydroxymethyl)-4-[(2S,3S,4R,5S,6S) 3,4,5trihydroxy-6-methyloxan-2-yl]oxyoxan3-yl]oxy-5-[(2S,3S,4S,5S,6R)-4,5-dihydroxy 6[[(2S,3S,4S,5S,6R)-3,4,5-trihydroxy-6(hydroxymethyl)oxan-2-yl] oxymethyl]-3 [(2S,3R,4S,5R)-3,4,5-trihydroxyoxan-2-yl] oxyoxan-2-yl]oxy-4-hydroxy-6 (hydroxymethyl)oxan-3-yl]acetamide. The chemical structure has been drawn by ChemDraw Professional software (Figure 5).

Pineapple peel extract demonstrates antibacterial properties because it contains chemical compounds. In addition to flavonoids as the highest concentration of chemical compounds in pineapple peel extract, there are other active compounds, namely: saponins, tannins, and enzymes bromelain. Each of these chemical compounds has a specific role in inhibiting the growth of Enterococcus faecalis [42] [75]. Flavonoid compounds have the ability to form complex bonds with extracellular protein through hydrogen bonding. Hydrogen bonds with extracellular proteins cause bacterial cell membrane structures containing proteins to become unstable. Consequently, the permeability of bacterial cell wall will be disrupted, resulting in bacterial cell death [76]. Tannin compounds can damage bacterial cell membranes and result in reduced permeability, so the growth and activities at bacterial cells is inhibited [77]. In other chemical compounds, saponin, as an antibacterial agent, can reduce the surface tension leading to the increasing

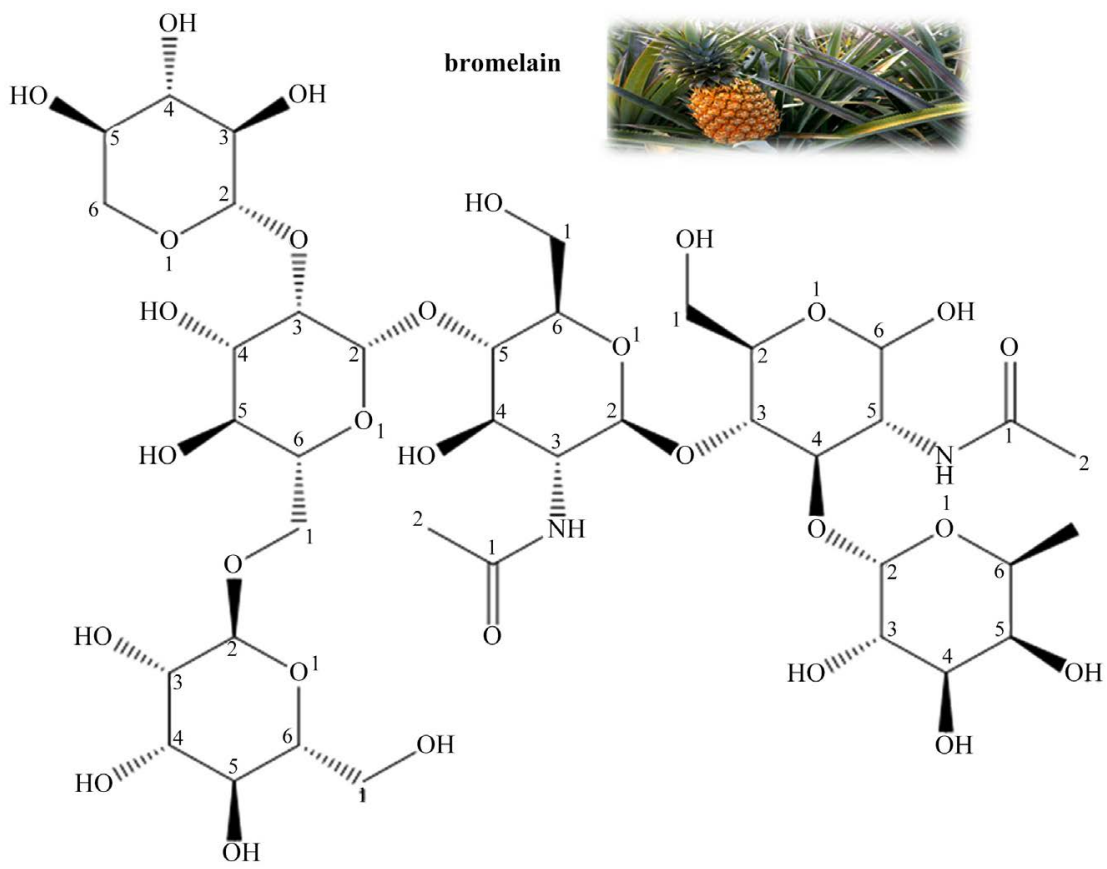

Figure 5. Chemical structure of bromelain. 
permeability of cell membranes. Changes in cell membrane permeability cause release of intracellular compounds from the cell that leads to bacterial lysis [77]. The action mechanism of the bromelain enzyme as an antimicrobial lies in altering or damaging the wall structure of bacteria-containing protein. The bromelain enzyme will break down and denature the protein constituent of bacterial cell walls. As the cell weakens it can allow small molecule to leak out [70]. Okoh et al. [44] performed the antibacterial activity of the peel extract and showed a greater inhibition for Staphylococcus aureus, Pseudomonas aeruginosa and Salmonella typhi. The data obtained show that the pineapple peel contains potential antimicrobial component that may be of great use for the development of pharmaceutical based therapies against various diseases. Drinking the juice or its peel eating can help to hydrate the body and restore the immune system.

\subsection{Antifungal Activity}

Olakunle et al. [78] investigated the antifungal activity and phytochemical analysis of selected fruit peels (orange, pineapple cashew and banana fruits). Extracts were prepared from each powder using water and ethanol as solvents. The antimicrobial activity of each of the aqueous extracts $(100 \mathrm{mg} / \mathrm{ml})$ against Aspergillus niger and Alternaria alternata. Results obtained showed that Aspergillus niger had its respective inhibition zones with orange, cashew, pineapple, and banana peel extracts as $0.33 \pm 0.33,0.40 \pm 0.30,0.60 \pm 0.20$ and $0.87 \pm 0.33 \mathrm{~cm}$ while inhibition zones of Alternaria alternata with the peels in the same order were $0.50 \pm 0.50,0.60 \pm 0.35,0.87 \pm 0.43$ and $1.37 \pm 0.67 \mathrm{~cm}$. Hence, the order of antifungal activity of the peel extracts against Aspergillus niger and Alternaria alternata was banana $>$ pineapple $>$ cashew $>$ orange. The antifungal activity of these peel extracts could be due to different classes of compounds such as alkaloid, flavonoid, tannin, cardiac glycoside, saponin and phlobatannin found in them. The phytochemical constituents of ethanolic extracts of pineapple peels were alkaloid, tannin and cardiac glycoside [78]. Antimicrobial properties of plants extracts had been attributed to the presence of alkaloids and flavonoids [79] [80] [81]. Phytochemicals with bitter taste such as alkaloids and flavonoids have been found to possess microbial properties and the presence of cardiac glycosides, flavonoids and alkaloids suggest that the possible antimicrobial activity was due to the presence of these phytochemicals in the peels. These bioactive groups of natural products have been reported for their inhibition roles against pathogens in ethnobotany, drug application and plant health management [82] [83]. These results have opened up the possibility of the use of peels in the treatment of fruits against spoilage microorganisms. The peels are novel, natural and economic sources of antimicrobics, which can be used in the control of post-harvest diseases [78].

\subsection{Other Uses}

Along the pineapple processing chain, waste products such as peels, crowns, stems 
and cores result, and these parts are usually containing significant amounts of the enzyme bromelain [84] [85]. Bromelain, a protease found in pineapples, is of high demand in the pharmaceutical, cosmetic and in the food industries, which use as a meat tenderiser, anti-browning agent and in the production of infant formulas [86]. As a protease, it hydrolyses proteins in these formulas, thus making amino acids more readily available to infants. Cosmetic and pharmaceutical usage of bromelain, as well as usage in the textile industry, has also been reported [87] [88] [89] [90].

Pineapple peel has the potential to being used as a nonpharmacological treatment in the form of processed food and instant drinks. One of the causes of hypertension is reduction of intracellular potassium concentrations in the body. Increased potassium intake could be done by consuming pineapple, because it is one of the superior fruits which have a high content of potassium [91]. Safriani et al. [91] showed that potassium levels in pineapple peel were $938.48 \mathrm{mg} / \mathrm{kg}$. The potassium content is greater than flesh and core which are $485.28 \mathrm{mg} / \mathrm{kg}$ and $12.98 \mathrm{mg} / \mathrm{kg}$, respectively. From the result, it was appeared that, the peel contains more potassium than flesh and core. Also, producing vinegar from fermented pineapple by-products (peels). The vinegar was produced after fermenting the peels of pineapple using three selected strains of acetic acid bacteria. such as propionic bacterium acidipropionici, panteo agglomerans, and pantea dispersa. The results of Chalchisa et al. [92] work have revealed that it is possible to produce vinegar from pineapple peels. This was done via the use of yeast ( Saccharomyces cerevisae) as an aerobic degradation of sugar to ethanol and Acetobacter aceti oxidizers ethanol to acetic acid (vinegar) by using different strain of acetic acid bacterias. The study also revealed that while cleaning the environment, an added value can be achieved through recycle or conversion of supposed wastes into useful products [93]. In addition to pineapples consumption as fresh, cooked, juiced, and preserved and are found in a wide array of cuisines., the pineapple leaves are used to produce the textile fibre pina employed as a component of wallpaper and furnishings, among other uses. Pineapple peel, is normally used as animal feed [94], development of new products such as cereal bars [95] [96], cakes [97] and jellies [31] [98], citric acid extraction [31], phenolic compounds production [31], bromelain from stem and rind [31], hydrogel from peel cellulose [31], nanocellulose from leaf fibres [32].

Generally, Pineapple peel waste (PPW) has been used for animal feed or land fertilizer [99], and substrate for production of bio-ethanol [41]. Antioxidant or reducing agent plays an important role both in health sector and chemical industry. Therefore, explored PPW as a potential of natural antioxidant is one of interesting pineapple applications as reducing agent is in biosynthesis of metal nanoparticles. It is found that biosynthesis of metal nanoparticles can be carried out by aqueous pineapple extract [45], and had successfully produced silver and cooper nanoparticles. Although fruit is the most used part of plant, other parts (root, rhizome, leaf, cortex, and stem) also have various nutritional and medici- 
nal properties. Leaves, stem, and pineapple fruit have an important role in traditional medicine as good antioxidants, antidiabetics, vermicides, emmenagogues, and hypolipemic agents. They are also used in different stadiums of wound healing and as an anti-edematous and anti-inflammatory agents in healing of soft tissue injuries, as well as in the treatment of arthritis, hematoma, and necrotic tissue [100] [101] [102] [103] [104]. The root and fruit are either eaten or applied topically as an anti-inflammatory and as a proteolytic agent. It is traditionally used as an anti-helminthic agent in the Philippine. A root decoction is used to treat diarrhea [2] [3]; however, this fruit also has anti-inflammatory and digestive properties. The fruit can also be used to aid in digestion. It can clear bronchial passages in those suffering with pneumonia and bronchitis [2] [3] .

Pineapple has been used as a medicinal plant in numerous cultures, both Lawal [105] and Dabesor et al. [106] reported that the solvent extracts of the various parts of $A$. comosus exhibit antibacterial, antiviral, antifungal, antiparasitic and anti-inflammatory properties. Moreover, pineapple juice, can be taken to alleviate sore throat and seasickness. The functional bioactivity of a plant extract, in general, depends upon the presence of compounds such as polyphenols, carotenoids and chlorophyll [14] [107], due to the antioxidant activity of polyphenolic compounds [108]. Flavonoids, mainly present as colouring pigments in plants also function as potent antioxidants at various levels. Some studies showed that flavonoids could protect membrane lipids from oxidation [109]. The anti-inflammatory properties in the fruit help reduce the symptoms of arthritis, and help reduce pain after surgery and sport injuries. A. comosus juice is taken as a diuretic and to expediate labour, also as a gargle in cases of sore throat and as an antidote for sea sickness, also to expel intestinal worms; and as a drastic treatment for venereal diseases. In Africa the dried, powdered root is a remedy for edema. The crushed rind is applied on fractures and the rind decoction with rosemary is applied on hemorrhoids. Indians in Panama use the leaf juice as a purgative, emmenagogue and vermifuge [2] [3]. Figure 6 shows the health benefits of pineapple waste (Ali et al., 2020) [110].

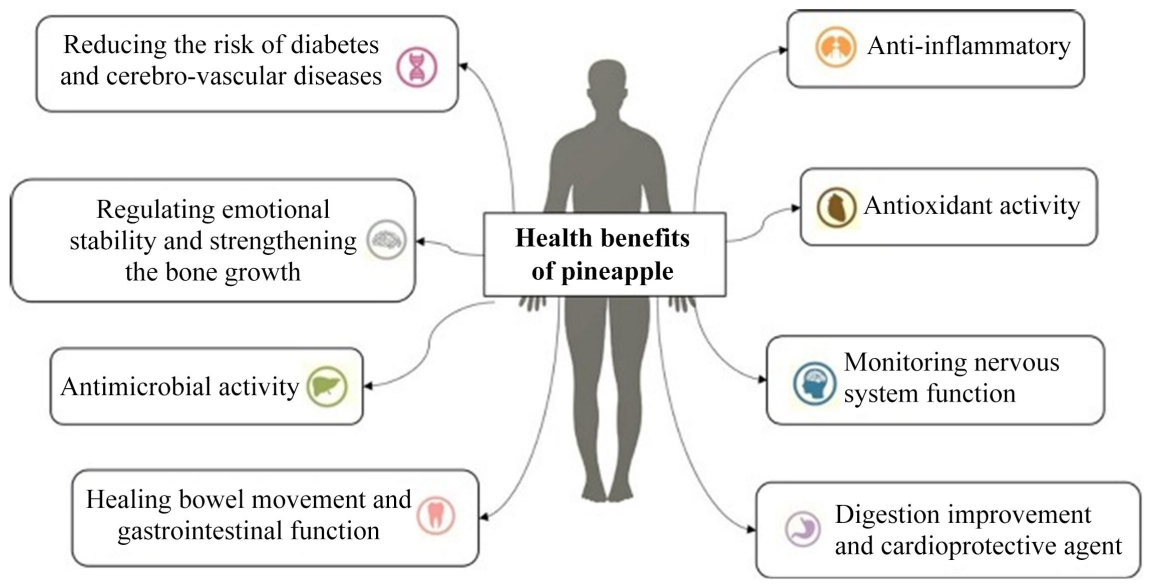

Figure 6. Health benefits of pineapple waste. 


\section{Conclusion}

Waste generated from pineapple fruit is an important concern in the context of effective waste management. Therefore, it is useful to exploit of such waste with a view to the optimal exploitation of the waste. By appropriate extraction technologies to extract important nutritional and bioactive components is an important concern in the waste. This study reviews pineapple peel as becomes a profitable by-product, given its unique aroma, abundant volatile compounds, and nutritional values and the processing of waste into food and other application. In pineapple waste, many reusable substances with a high final value are found. There are significant amounts of high-value bioactive compounds in various waste generated from pineapple, such as a crown, peel or skin, core, etc. The results obtained in this study showed that pineapple peel has varying degrees of antimicrobial activity, anticancer and antioxidant activities. The results also revealed the presence of medicinally important constituents in peel. Many evidences gathered in earlier studies have confirmed the identified phytochemicals to be bioactive. Therefore, pineapple peel could be used as a good source of nonpharmacological treatment in the form of processed food and instant drinks and a promising source of metabolites for therapeutics, functional foods, and cosmeceutical applications.

\section{Conflicts of Interest}

The authors declare no conflicts of interest regarding the publication of this paper.

\section{References}

[1] Ayala-Zavala, J.F., Rosas-Domínguez, C., Vega-Vega, V. and González-Aguilar, G.A. (2010) Antioxidant Enrichment and Antimicrobial Protection of Fresh-Cut Fruits Using Their Own by Products: Looking for Integral Exploitation. Journal of Food Science, 75, R175-R181. https://doi.org/10.1111/j.1750-3841.2010.01792.x

[2] Piana, C.F., Featherstone, A. and Boland, M. (2005) Vertical Integration in Ecuador: The Case of Fresh-Cut Pineapples. Review of Agricultural Economics, 4, 593-603.

[3] Jovanovic, M., Milutinovic, M., Kostic, M., Miladinovic, B., Kitic, N, Brankovic, S. and Kitic, D. (2018) Antioxidant Capacity of Pineapple (Ananas comosus (L.) Merr.) Extracts and Juice. Lekovite Sirovine, 38, 27-30. https://doi.org/10.5937/leksir1838027I

[4] FAO (2019) FAOSTAT. Food and Agricultural Commodities Production. Food and Agricultural Organization of the United Nations-FAO, Rome.

[5] Saloni, S., Chauhan, K. and Tiwari, S. (2017) Pineapple Production and Processing in North Eastern India. Journal of Pharmacognosy and Phytochemistry, 1, 665-672.

[6] Salve, R.R. and Ray, S. (2020) Comprehensive Study of Different Extraction Methods of Extracting Bioactive Compounds from Pineapple Waste-A Review. The Pharma Innovation International Journal, 9, 327-340.

[7] Chen, H., Hu B., Zhao, L., Shi, D, She, Z., Huang, X., Priyadarshani, S.V.G.N, Niu, X. and Qin, Y. (2019) Differential Expression Analysis of Reference Genes in Pineapple (Ananas comosus L.) during Reproductive Development and Response to 
Abiotic Stress, Hormonal Stimuli. Tropical Plant Biology, 12, 67-77. https://doi.org/10.1007/s12042-019-09218-2

[8] Yabor, L., Pérez, L., Gómez, D., Villalobos-Olivera, A., Mendoza, J.R., Martínez, J., Escalante, D., Garro, G., Hajari, E. and Lorenzo, J.C. (2020) Histological Evaluation of Pineapple Transgenic Plants Following 8 Years of Field Growth. Euphytica, 216, Article No. 23. https://doi.org/10.1007/s10681-020-2555-6

[9] Marcellini, P.S., Delisa, R. and Bolini, H.M.A. (2006) Caracterização sensorial de suco de abacaxi concentrado, reconstituído e adoçado com diferentes edulcorantes e sacarose. Alimentos e Nutrição, 17, 143-150.

[10] Pinheiro, A.C.M., Vilas Boas, E.V.B. and Lima, L.C. (2005) Influência do CaCl2 sobre a qualidade pós-colheita do abacaxi cv. Pérola. Ciência e Tecnologia de Alimentos, 25, 32-36. https://doi.org/10.1590/S0101-20612005000100006

[11] Difonzo, G., Vollmer, K., Caponio, F, Pasqualone, A., Carle, R. and Steingass, C.B. (2019) Characterisation and Classification of Pineapple (Ananas comosus [L.] Merr.) Juice from Pulp and Peel. Food Control, 96, 260-270. https://doi.org/10.1016/j.foodcont.2018.09.015

[12] Tokitomo, Y. (2007) Aroma of Pineapple. Foods and Food Ingredients Journal of Japan, 212, 949-956.

[13] Kumar, A. (2021) Utilization of Bioactive Components Present in Pineapple Waste: A Review. The Pharma Innovation Journal, 10, 954-961

[14] Hossain, M.A., Rahman, S.M.M. (2011) Total Phenolics, Flavonoids and Antioxidant Activity of Tropical Fruit Pineapple. Food Research International, 44, 672-676. https://doi.org/10.1016/j.foodres.2010.11.036

[15] Abdullah, A. (2007) Solid and Liquid Pineapple Waste Utilization for Lactic Acid Fermentation Using Lactobacillus delbrueckii. Reaktor, 11, 50-52. https://doi.org/10.14710/reaktor.11.1.50-52

[16] Conesa, C., García-Breijo, E., Loeff, E., Seguí, L., Fito, P. and Laguarda-Miró, N. (2015) An Electro Chemical Impedance Spectroscopy-Based Technique To identify and Quantify Fermentable Sugars in Pineapple Waste Valorization for Bioethanol Production. Sensors, 15, 22941-22955. https://doi.org/10.3390/s150922941

[17] Seleni, M.M., Canniatti, S.G., Dos Santos, C.T., Ratnayake, W.S., Flores, R.A. and Bianchini, A. (2014) Characterization and Potential Application of Pineapple Pomace in an Extruded Product for Fiber Enhancement. Food Chemistry, 163, 23-30. https://doi.org/10.1016/j.foodchem.2014.04.076

[18] Santa-meridas, O., Gonzalez, A. and Sanchez-Vioque, R. (2012) Agricultural Residues as a Source of Bioactive Natural Products. Phytochemistry Review, 11, 447-466. https://doi.org/10.1007/s11101-012-9266-0

[19] Lin, C., Koutinas, A., Stamatelatou, K., Mubofu, E., Matharu, A., Kopsahelis, N. and Luque, R. (2014) Current and Future Trends in Food Waste Valorization for the Production of Chemicals, Materials and Fuels: A Global Perspective. Biofuels Bioproducts \& Biorefinering, 8, 686-715. https://doi.org/10.1002/bbb.1506

[20] Sepúlveda, L., Romaní, A., Aguilar, C.N. and Teixeira, J. (2018) Valorization of Pineapple Waste for the Extraction of Bioactive Compounds and Glycosides Using Autohydrolysis. Innovative Food Science and Emerging Technologies, 47, 38-45. https://doi.org/10.1016/j.ifset.2018.01.012

[21] Larrauri, J.A., Rupérez, P. and Calixto, F.S. (1997) Pineapple Shell as a Source of Dietary Fiber with Associated Polyphenols. Journal of Agricultural and Food Chemistry, 45, 4028-4031. https://doi.org/10.1021/jf970450j

[22] Upadhyay, A., Prava-Lama, J. and Tawata, S. (2010) Utilization of Pineapple Waste: 
A Review. Journal of food science technology Nepal, 6, 10-18. https://doi.org/10.3126/jfstn.v6i0.8255

[23] Cuevas, M., García, J.F., Hodaifa, G. and Sánchez, S. (2015) Oligosaccharides and Sugars Production from Olive Stones by Autohydrolysis and Enzymatic Hydrolysis. Industrial Crops and Products, 70, 100-106. https://doi.org/10.1016/j.indcrop.2015.03.011

[24] Díaz-Vela, J., Totosaus, A., Cruz-Guerrero, A. and Pérez-Chabela, M.L. (2013) In Vitro Evaluation of the Fermentation of Added-Value Agro-Industrial By-Products: Cactus Pear (Opuntia ficus-indica L.) Peel and Pineapple (Ananas comosus) Peel as Functional Ingredients. International Journal of Food Science and Technology, 48, 1460-1467. https://doi.org/10.1111/ijfs.12113

[25] Said-Al Ahl, H.A.H., Astatkie, T. and Hikal, W.M. (2017) Opuntia Ficus-Indica (Cactus Pear) Multipurpose Plant for the Future. Noor Publishing, Saarbrücken.

[26] Hikal, W.M., Said-Al Ahl, H.A.H. and Tkachenko, K.G. (2020) Present and Future Potential of Antiparasitic Activity of Opuntia ficus-indica. Tropical Journal of Natural Product Research, 4, 672-679. https://doi.org/10.26538/tjnpr/v4i10.3

[27] Hikal, W.M., Said-Al Ahl, H.A.H. and Kacaniova, M. (2021) A Review of Antimicrobial Activities of Cactus (Opuntia ficus-indica). Asian Journal of Research in Biosciences, 3, 10-17.

[28] Silvestre, M., Carriera, R., Silva, M., Corgosinho, F., Monteiro, M. and Morais, H. (2012) Effect of $\mathrm{pH}$ and Temperature on the Activity of Enzymatic Extracts from Pineapple Peel. Food and Bioprocess Technology, 5, 1824-1831. https://doi.org/10.1007/s11947-011-0616-5

[29] Bruneton, J. (1999) Pharmacognosy, Phytochemistry, Medicinal Plants. 3rd Edition, Intercept Ltd., Hampshire, 385-386.

[30] Boteliho, L., Conceicao, A. and Carvalho, V.D. (2002) Caracterização de fibras alimentares da casca e cilindro central do abacaxi 'Smooth Cayenne'. Ciências Agrotécnicas, 26, 362-367.

[31] Mamo, J. and Assefa, F. (2019) Antibacterial and Anticancer Property of Bromelain: A Plant Protease Enzyme from Pineapples (Ananas comosus). Current Trends in Biomedical Engineering and \& Biosciences, 19, Article ID: 556009.

[32] Cherian, B.M., Leao, A.L., de Sousa, S.F., Thoma, S., Pothan, L.A. and Kottaisamy, M. (2010) Isolation of Nanocellulose from Pineapple Leaf Fibres by Steam Explosion. Carbohydrate Polymers, 81, 720-725. https://doi.org/10.1016/j.carbpol.2010.03.046

[33] Idris, A. and Suzana, W. (2006) Effect of Sodium Alginate Concentration, Bead Diameter, Initial $\mathrm{pH}$, and Temperature on Lactic Acid Production from Pineapple Waste Using Immobilized Lactobacillus delbrueckii. Process Biochemistry, 41, 1117-1123. https://doi.org/10.1016/j.procbio.2005.12.002

[34] Ketnawa, S., Sai-Ut, S., Theppakorn, T., Chaiwut, P. and Rawdkuen, S. (2009) Partitioning of Bromelain from Pineapple Peel (Nang Lae cultv.) by Aqueous Two-Phase System. Asian Journal of Food and Agro-Industry, 2, 457-468.

[35] Gorinstein, S., Zemser, M., Haruenkit, R., Chuthakorn, R., Grauer, F., Martin-Belloso, O. and Trakhtenberg, S. (1999) Comparative Content of Total Polyphenols and Dietary Fiber in Tropical Fruits and Persimmon. Journal of Nutritional Biochemistry, 10, 367-371. https://doi.org/10.1016/S0955-2863(99)00017-0

[36] Alejandra, R. and Emperatriz, P.D.D. (2011) Chemical Composition and Bioactive Compounds in Pineapple, Guava, and Soursop Pulp. Interciencia, 36, 71-75. 
[37] Yahya, N.A., Abdul Wahab, R., Xine, T.L.S. and Abdul Hamid, M. (2019) Ultrasound-Assisted Extraction of Polyphenols from Pineapple Skin. Proceedings of the 2nd International Conference on Biosciences and Medical Engineering (ICBME 2019), 2155, Article ID: 020002.https://doi.org/10.1063/1.5125506

[38] Romelle, F.D., Rani, P.A. and Manohar, R.S. (2016) Chemical Composition of Some Selected Fruit Peels. European Journal of Food Science and Technology, 4, 12-21.

[39] Hajar, N., Zainal, S., Nadzirah, K.Z., Roha, A.M.S., Atikah, O. and Elida, T.Z.M.T. (2012) Physicochemical Properties Analysis of Three Indexes Pineapple (Ananas comosus) Peel Extract Variety N36. APCBEE Procedia, 4, 115-121. https://doi.org/10.1016/j.apcbee.2012.11.020

[40] Hemalatha, R. and Anbuselvi, S., (2013) Physicochemical Constituents of Pineapple Pulp and Waste. Journal of Chemical and Pharmaceutical Research, 5, 240-242.

[41] Saraswaty, V., Risdian, C., Primadona, I., Andriyani, R., Andayani, D.G.S. and Mozef, T. (2017) Pineapple Peel Wastes as a Potential Source of Antioxidant Compounds. 1 st International Symposium on Green Technology for Value Chains, 2016 3-5 October 2016, Tangerang, Article ID: 012013. https://doi.org/10.1088/1755-1315/60/1/012013

[42] Arsyada, I.F., Rianti, D. and Munadziroh, E. (2018) Antibacterial Activity of Mixed Pineapple Peel (Ananas comosus) Extract and Calcium Hydroxide Paste against Enterococcus faecalis. Dental Journal, 51, 20-24.

https://doi.org/10.20473/j.djmkg.v51.i1.p20-24

[43] Thanish, A.S., Vishnu, P.V., Gayathri, R. and Geetha, R.V. (2016) Evaluation of Antimicrobial Activity of Pineapple Extract against Selected Oral Pathogen. International Journal of Pharmaceutical Sciences Review and Research, 8, 491-492.

[44] Okoh, M.E., Obadiah, H.I. and Aiyamenkue, J. (2019) Antimicrobial Activities of Pineapple Peel (Ananas comosus) Extract on Selected Microbes. Biological Reports, 4,11 .

[45] Ahmad, N. and Sharma, S. (2012) Green Synthesis of Silver Nanoparticles Using Extracts of Ananas comosus. Green and Sustainable Chemistry, 2, 141-147. https://doi.org/10.4236/gsc.2012.24020

[46] Morais, M.M. and Silva M.A. (2011) Retenção de aroma na secagem em atmosfer as normal e modificada. desenvolvimento do sistema de estudo. Ciência e Tecnologia de Alimentos, 31, 295-302. https://doi.org/10.1590/S0101-20612011000200003

[47] Facundo, H.V.V. (2009) Mudanças no perfil sensorial e de voláteis do suco de abacaxi concentrado durante o processamento. Dissertação (Mestrado em Tecnologia de Alimentos), Faculdade de Engenharia de Alimentos, Universidade Federal do Ceará, Fortaleza.

[48] Elss, S., Preston, C., Hertzig, C., Heckel, F., Richling, E. and Schreier, P. (2005) Aroma Profiles of Pineapple Fruit (Ananas comosus [L.] Merr.) and Pineapple Products. LWT-Food Science and Technology, 38, 263-274. https://doi.org/10.1016/j.lwt.2004.07.014

[49] Spanier, A.M., Flores, M., James, C Lasater, J., Lloyd, S. and Miller, J.A. (1998) FreshCut Pineapple (Ananas sp.) Flavor. Effect of Storage. In: Contis, E.T., Ho, C.-T. and Mussinan, C.J., Eds., Food Flavors: Formation, Analysis and Packaging Influences: Proceedings of the 9 th International Flavor Conference, The George Charalambous Memorial Symposium, Elsevier, Amsterdam, 331-343. https://doi.org/10.1016/S0167-4501(98)80057-5

[50] Barretto, L.C.O, Moreira, J.J.S., dos Santos, J.A.B., Narain, N. and dos Santos, R.A.R. (2013) Characterization and Extraction of Volatile Compounds from Pineapple (Ananas 
comosus L. Merril) Processing Residues. Food Science and Technology, Campinas, 33, 638-645. https://doi.org/10.1590/S0101-20612013000400007

[51] Wei, C., Liu, S., Liu, Y., Lv, L., Yang, W. and Sun, G. (2011) Characteristic Aroma Compounds from Different Pineapple Parts. Molecules, 16, 5104-5112. https://doi.org/10.3390/molecules 16065104

[52] Tokitomo, Y., Steinhaus, M., Buttner, A. and Schieberle, P. (2005) Odor-Active Constituents in Fresh Pineapple (Ananas comosus [L.] Merr.) by Quantitative and Sensory Evaluation. Bioscience, Biotechnology, and Biochemistry, 69, 1323-1330. https://doi.org/10.1271/bbb.69.1323

[53] Zhang, L., Zhou, C., Yuan, Y., Gong, X., Hu, Y. and Li, J. (2020) Characterisation of Volatile Oil Compounds of Pineapple Peel Wine. International Conference on Environment, Energy and Biotechnology (ICEEB 2020), 22-24 July 2020, Jeju Island, 4 p. https://doi.org/10.1051/e3sconf/202018504065

[54] de Oliveira, A.C., Valentim, I.B., Silva, C.A., Bechara, E.J.H., Barros, M.P., Mano, C.M. and Goulart, M.O.F. (2009) Total Phenolic Content and Free Radical Scavenging Activities of Methanolic Extract Powders of Tropical Fruit Peels. Food Chemistry, 115, 469-475. https://doi.org/10.1016/j.foodchem.2008.12.045

[55] Li, T., Shen, P., Liu, W., Liu, C., Liang, R. and Yan, N.J. (2014) Major Polyphenolics in Pineapple Peels and Their Antioxidant Interactions. International Journal of Food Properties, 17, 1805-1817. https://doi.org/10.1080/10942912.2012.732168

[56] Saravanan, P., Muthuvelayudham, R. and Viruthagiri, T. (2013) Enhanced Production of Cellulase from Pineapple Waste by Response Surface Methodology. Journal of Engineering, 2013, Article ID: 979547. https://doi.org/10.1155/2013/979547

[57] de Moraes Crizel, T., Hermes, V.S., de Oliveira Rios, A. and Flôres, S.H. (2016) Evaluation of Bioactive Compounds, Chemical and Technological Properties of Fruits by Products Powder. Journal of Food Science and Technology, 53, 4067-4075. https://doi.org/10.1007/s13197-016-2413-7

[58] Santos, M.C.P. and Gonçalves, É.C.B.A. (2016) Effect of Different Extracting Solvents on Antioxidant Activity and Phenolic Compounds of a Fruit and Vegetable Residue Flour. Scientia Agropecuaria, 7, 7-14. https://doi.org/10.17268/sci.agropecu.2016.01.01

[59] Rawson, A., Patras, A., Tiwari, B.K., Noci, F., Koutchma, T. and Brunton, N. (2011) Effect of Thermal and Non-Thermal Processing Technologies on the Bioactive Content of Exotic Fruits and Their Products: Review of Recent Advances. Food Research International, 44, 1875-1887. https://doi.org/10.1016/j.foodres.2011.02.053

[60] Kidmose, U., Hansen, S.L., Christensen, L.P., Edelenbos, M., Larsen, E. and Nørbæk, R. (2004) Effects of Genotype, Root Size, Storage, and Processing on Bioactive Compounds in Organically Grown Carrots (Daucus carota L.). Journal of Food Science, 69, S388-S394. https://doi.org/10.1111/j.1365-2621.2004.tb09955.x

[61] Rawson, A., Tiwari, B.K., Patras, A., Brunton, N., Brennan, C., Cullen, P.J. and O’Donnell, C. (2011) Effect of Thermosonication on Bioactive Compounds in Watermelon Juice. Food Research International, 44, 1168-1173.

https://doi.org/10.1016/j.foodres.2010.07.005

[62] Puupponen-Pimiä, R., Häkkinen, S.T., Aarni, M., Suortti, T., Lampi, A.-M., Eurola, M., Piironen, V., Nuutila, A.M. and Oksman-Caldentey, K.M. (2003) Blanching and Long-Term Freezing Affect Various Bioactive Compounds of Vegetables in Different Ways. Journal of the Science of Food and Agriculture, 83, 1389-1402. https://doi.org/10.1002/jsfa.1589

[63] Okafor, O.Y., Erukainure, O.L., Ajiboye, J.A., Adejobi, R.O., Owolabi, F.O. and 
Kosoko, S.B. (2011) Modulatory Effect of Pineapple Peel Extract on Lipid Peroxidation, Catalase Activity and Hepatic Biomarker Levels in Blood Plasma of Alcohol Induced Oxidative Stressed Rats. Asian Pacific Journal of Tropical Biomedicine, 1, 12-14. https://doi.org/10.1016/S2221-1691(11)60060-9

[64] Lourenço, S.C., Fraqueza, M.J., Fernandes, M.H., Moldão-Martins, M. and Alves, V.D. (2020) Application of Edible Alginate Films with Pineapple Peel Active Compounds on Beef Meat Preservation. Antioxidants, 9, 667.

https://doi.org/10.3390/antiox9080667

[65] Azizan, A., Lee, A.X., Abdul Hamid, N.A., Maulidiani, M., Mediani, A., Abdul Ghafar, S.Z., Zolkeflee, N.K.Z. and Abas, F. (2020) Potentially Bioactive Metabolites from Pineapple Waste Extracts and Their Antioxidant and $\alpha$-Glucosidase Inhibitory Activities by 1H NMR. Foods, 9, 173. https://doi.org/10.3390/foods9020173

[66] Jayashree, J., Priya, D., Karthikeyan, S. and Ramesh Babu, N.G. (2017) Production And characterization of Ferulic Acid from Pineapple Waste and Its Anticancer Activity Using HeLa Cell Line. International Journal of Innovative Research in Science, Engineering and Technology, 6, 1-6.

[67] Lubaina, A.S., Renjith, P.R. and Kumar, P. (2019) Antibacterial Potential of Different Extracts of Pineapple Peel against Gram-Positive and Gram-Negative Bacterial Strains. Asian Journal of Pharmacy and Pharmacology, 5, 66-70.

https://doi.org/10.31024/ajpp.2019.5.s1.5

[68] Das, G., Patra, J.K., Debnath, T., Ansari, A. and Shin, H.-S. (2019) Investigation of Antioxidant, Antibacterial, Antidiabetic, and Cytotoxicity Potential of Silver Nanoparticles Synthesized Using the Outer Peel Extract of Ananas comosus (L.). PLoS ONE, 14, e0220950. https://doi.org/10.1371/journal.pone.0220950

[69] Maurer, H.R. (2001) Bromelain: Biochemistry, Pharmacology and Medical Use. Cellular and Molecular Life Sciences, 58, 1234-1245.

https://doi.org/10.1007/PL00000936

[70] Eshamah, H., Han, I., Naas, H., Rieck, J. and Dawson, P. (2013) Bactericidal Effects of Natural Tenderizing Enzymes on Escherichia coli and Listeria monocytogenes. Journal of Food Research, 21, 8-18. https://doi.org/10.5539/jfr.v2n1p8

[71] Korir, R.K., Mutai, C., Kiiyukia, C. and Bii, C. (2012) Antimicrobial Activity and Safety of Two Medicinal Plants Traditionally Used in Bomet District of Kenya. Research Journal of Medicinal Plant, 6, 370-382. https://doi.org/10.3923/rjmp.2012.370.382

[72] Boudet, A.M. (2007) Evolution and Current Status of Research in Phenolic Compounds. Phytochemistry, 68, 2722-2735. https://doi.org/10.1016/j.phytochem.2007.06.012

[73] Akinpelu, D.A., Adegboye, M.F., Adeliye, O.A. and Okoh, A.I. (2008) Biocidal Activity of Partially Purified Fractions from Mathanolic Extract of (Heckel) Seeds on Garcinia kolabacterial Isolates. Biological Research, 41, 277-287. https://doi.org/10.4067/S0716-97602008000300005

[74] Bhagavathy, S., Gayathridevi, R., Pushya, K. and Jeniffer, J. (2019) Screening, Optimization and Antimicrobial Activity of Bromelain from Ananas comosus. International Journal of Scientific Development and Research, 4, 233-240. https://doi.org/10.21839/jaar.2019.v4i5.304

[75] Kriplani, R., Thosar, N., Baliga, M.S., Kulkarni, P., Shah, N. and Yeluri, R. (2013) Comparative Evaluation of Antimicrobial Efficacy of Various Root Canal Filling Materials along with Aloe vera Used in Primary Teeth: A Microbiological Study. Journal of Clinical Pediatric Dentistry, 37, 257-262.

https://doi.org/10.17796/jcpd.37.3.j62u53q2300484x5 
[76] Manimozhi, D.M., Sankaranarayanan, S. and Sampathkumar, G. (2012) Evaluating the Antibacterial Activity of Flavonoids Extracted from Ficus benghalensis. International Journal of Pharmaceutical and Biological Research, 3, 7-18.

[77] Ngajow, M., Abidjulu, J. and Kamu, V.S. (2013) Pengaruh Antibakteri Ekstrak Kulit Batang Matoa (Pometia pinnata) Terhadap Bakteri Staphylococcus aureus Secara in Vitro. Journal MIPA Unsrat Online, 2, 128-132. https://doi.org/10.35799/jm.2.2.2013.3121

[78] Olakunle, O.O., Joy, B.D. and Irene, O.J. (2019) Antifungal Activity and Phytochemical Analysis of Selected Fruit Peels. Journal of Biology and Medicine, 3, 40-43. https://doi.org/10.17352/jbm.000013

[79] Hutchings, M.R., Athanasiadous, S., Kynazakis, I. and Gordon, I.J. (2003) Can Animals Use Foraging Behavior to Combat Parasites? Proceedings of Nutrition Society, 62, 361-370. https://doi.org/10.1079/PNS2003243

[80] Okorondu, S.I., Sokari, T.G., Akujobi, C.O. and Braide, W. (2010) Phytochemical and Antibacterial Properties of Musa paradisica Stalk Plant. International Journal of Biological Science, 2, 128-132.

[81] Hikal, W.M., Kacaniova, M. and Said-Al Ahl, H.A.H. (2021) Banana Peels as Possible Antioxidant and Antimicrobial Agents. Asian Journal of Research and Review in Agriculture, 3, 35-45.

[82] Okwu, D.E. and Njoku, E.E. (2009) Chemical Composition and in Vitro Antifungal Activity Screening of Seed and Leaf Extracts from Afromonum melenguata and $\mathrm{Mo}$ nodora myristica against Sclerotium rolfsii of Cowpea Plant. Pest Technology, 3, 5862.

[83] Enyiukwu, D.N. and Awurum, A.N. (2013) Fungitoxic Principles and Antifungal Activity of Extracts from Carica papaya and Piper gurneense on Colletotrychum destructivum. Journal of Biological Science, 7, 29-36.

[84] Benefo, E.O. and Ofosu, I.W. (2018) Bromelain Activity of Waste Parts of Two Pineapple Varieties. Sustainable Food Production, 2, 21-28. https://doi.org/10.18052/www.scipress.com/SFP.2.21

[85] Bala, M., Smail, N.A., Mel, M., Jami, M.S., Salleh, H.M. and Amid, A. (2012) Bromelain Production: Current Trends and Perspective. Archives Des Sciences, 65, 369399.

[86] Tochi, B.N., Wang, Z., Xu, S. and Zhang, W. (2008) Therapeutic Application of Pineapple Protease (Bromelain): A Review. Pakistan Journal of Nutrition, 7, 513-520. https://doi.org/10.3923/pjn.2008.513.520

[87] Aehle, W. (2007) Enzymes in industry: Production and Applications. 3rd Edition, Wiley-VCH/Verlag GmbH \& Co., Weinheim. https://doi.org/10.1002/9783527617098

[88] Bhattacharrya, B.K. (2008) Bromelain: Overview. Natural Product Radiance, 7, 359363.

[89] Ataide, J.A., Gerios, E.F., Mazzola, P.G. and Souto, E.B. (2018) Bromelain-Loaded Nanoparticles: A Comprehensive Review of the State of the Art. Advances in Colloid and Interface Science, 254, 48-55. https://doi.org/10.1016/j.cis.2018.03.006

[90] Sancesario, G.M., Nuccetelli, M, Cerri, A., Zegeer, J., Severini, C., Ciotti, M.T., Pieri, M., Martorana, A., Caltagirone, C., Nistico, R. and Bernardini, S. (2018) Bromelain Degrades A $\beta 1-42$ Monomers and Soluble Aggregates: An in Vitro Study in Cerebrospinal Fluid of Alzheimer's Disease Patients. Current Alzheimer Research, 15, 628636. https://doi.org/10.2174/1567205015666180123124851 
[91] Safriani, N., Dewi, Y. and Lestari, O.A. (2018) Pineapple Peel (Ananas Comosus L. Merr) Can Be Used as Non-Pharmacological Treatment for Hypertension. International Conference on Pharmaceutical Research and Practice, Universitas Islam Indonesia, Yogyakarta, 15 December 2018, 154-158.

[92] Hale, L.P., Greer, P.K., Trinh C.T. and Gottfried, M.R. (2005) Treatment with Oral Bromelain Decreases Colonic Inflammation in the IL-10-Deficient Murine Model of Inflammatory Bowel Disease. Clinical and Immunology, 116, 135-142. https://doi.org/10.1016/j.clim.2005.04.011

[93] Chalchisa, T. and Dereje, B. (2021) From Waste to Food: Utilization of Pineapple Peels for Vinegar Production. MOJ Food Processing \& Technology, 9, 1-5.

[94] Punbusayakul, N., Samart, K. and Sudmee, W. (2018) Antimicrobial Activity of Pineapple Peel Extract. The first International Conference on Functional Food Innovation in Asia (IFFA 2018), Phayao, 2-24 January 2 2018, 141-149.

[95] Paiva, A.P., Barcelos, M.F.P., Pereira, J.A., Ferreira, E.B. and Ciabott, S. (2012) Characterization of Food Bars Manufactured with Agroindustrial By-Products and Waste. Food Science and Technology-Ciência e Agrotecnologia, 36, 333-340. https://doi.org/10.1590/S1413-70542012000300009

[96] Fonseca, R.S., Del Santo, V.R., de Souza, G.B. and Pereira, C.A.M. (2011) Elaboração de barra de cereais com casca de abacaxi. Archivos Latinoamericanos de Nutrición, 61, 216-223.

[97] Martin, J.G.P. Matta Júnior, D.M., de Almeida, M.A., dos Santos, T. and Spoto, M.H.F. (2012) Avaliação sensorial de bolo com resíduo de casca de abacaxi para suplementação do teor de fibras. Revista Brasileira de Produtos Agroindustriais, 14, 281-287. https://doi.org/10.15871/1517-8595/rbpa.v14n3p281-287

[98] Lemos, D.M., de Oliveira, E.N.A., Santos, D.C., de Sousa, E.P. and Matias, M.L. (2010) Composição físico-química de resíduos de abacaxi in natura e desidratado. Tecnologia \& Ciência Agropecuária, 4, 53-56.

[99] Makinde, O.A., Odeyinka, S.M. and Ayandiran, S.K.L. (2011) Simple and Quick Method for Recycling Pineapple Waste into Animal Feed. Livestock Research for Rural Development, 23, 9 .

[100] Bartholomew, D.P., Paull, R.E. and Rohrbach, K.G. (2003). The Pineapple: Botany, Production and Uses. CABI, Wallingford.

https://doi.org/10.1079/9780851995038.0000

[101] Dutta, S. and Bhattacharyya, D. (2013). Enzymatic, Antimicrobial and Toxicity Studies of the Aqueous Extract of Ananas comosus (Pineapple) Crown Leaf. Journal of Ethnopharmacology, 150, 451-457. https://doi.org/10.1016/j.jep.2013.08.024

[102] Saxena, P. and Panjwani, D. (2014) Cardioprotective Potential of Hydro-Alcoholic Fruit Extract of Ananas comosus against isoproterenol Induced Myocardial Infarction in Wistar Albino Rats. Journal of Acute Disease, 3, 228-234. https://doi.org/10.1016/S2221-6189(14)60051-2

[103] Xie, W., Wang, W., Su, H., Xing, D., Pan, Y. and Du, L. (2006) Effect of Ethanolic Extracts of Ananas comosus L. Leaves on Insulin Sensitivity in Rats and HepG2. Comparative Biochemistry and Physiology Part C. Toxicology \& Pharmacology, 143, 429435. https://doi.org/10.1016/j.cbpc.2006.04.002

[104] Xie, W., Xing, D., Sun, H., Wang, W., Ding, Y. and Du, L. (2005) The Effects of Ananas comosus L. Leaves on Diabetic-Dyslipidemic Rats Induced by Alloxan and a HighFat/High-Cholesterol Diet. The American Journal of Chinese Medicine, 33, 95-105. https://doi.org/10.1142/S0192415X05002692

[105] Lawal, D. (2013) Medicinal, Pharmacological and Phytochemical Potentials of Ananas 
comosus Linn. Peel-A Review. Bayero Journal of Pure and Applied Sciences, 6, 101 104. https://doi.org/10.4314/bajopas.v6i1.21

[106] Dabesor, A.P., Asowata-Ayodele, A.M. and Umoiette, P. (2017) Phytochemical Compositions and Antimicrobial Activities of Ananas comosus Peel (M.) and Cocos nucifera Kernel (L.) on Selected Food Borne Pathogens. American Journal of Plant Biology, 2, 73-76.

[107] Choi, Y. and Lee, J. (2009) Antioxidant and Antiproliferative Properties of a Tocotrienol Rich Fraction from Grape Seeds. Food Chemistry, 114, 1386-1390. https://doi.org/10.1016/j.foodchem.2008.11.018

[108] Higdon, J.V. and Frei, B. (2003) Tea Catechins and Polyphenols: Health Effects, Metabolism and Antioxidant Functions. Critical Reviews in Food Science and Nutrition, 43, 89-143. https://doi.org/10.1080/10408690390826464

[109] Terao, J., Piskula, M. and Yao, Q. (1994) Protective Effect of Epicatechin, Epicatechin Gallate, and Quercetin on Lipid Peroxidation in Phospholipid Bilayers. Archives of Biochemistry and Biophysics, 308, 278-284. https://doi.org/10.1006/abbi.1994.1039

[110] Ali, M.M., Hashima, N., Abd Aziz, S. and Lasekan, O. (2020) Pineapple (Ananas comosus): A Comprehensive Review Of Nutritional Values, Volatile Compounds, Health Benefits, and Potential Food Products. Food Research International, 137, Article ID: 109675. https://doi.org/10.1016/j.foodres.2020.109675 